UDC $543.422 .3 ; 543.42 .062 ; 535.8$

\title{
RESEARCH INTO REACTIONS OF CHROME (VI) COMPLEXATION WITH 2- HYDROXY-5-IODIOPHENOL IN THE PRESENCE OF HYDROPHOBIC AMINES
}

\author{
N.S. Hasanova \\ Azerbaijan State University of Oil and Industry \\ Azadlg str. 34, Az 1000 Baku, e-mail: hesenova.1969@inbox.ru
}

Received 16.09.2019

\begin{abstract}
Spectrophotometric methods were used to study the complexation of chromium (VI) with 2hydroxy-5-iodothiophenol (HITP) in the presence of hydrophobic amines. Out of hydrophobic amines $(\mathrm{Am})$, there were used o-oxylidine and $m$-xylidine. Chloroform, dichloroethane and chlorobenzene proved to be the best extractants. Following a single extraction with chloroform, 97.4-98.8\% of chromium was extracted as an ionic associate. It revealed that mixed ligand complexes are formed in a weakly acidic medium ( $\mathrm{pH}$ 0.2-6.9). For the formation and extraction of MLC, a 26-30-fold excess of complexing agents is required. For example, optimal conditions for the formation and extraction of these compounds are provided at $1.0 \times 10^{-3} \mathrm{M}$ HITP and $(1.12-1.16) \times 10^{-3} \mathrm{M} \mathrm{Am}$. Maximum in the absorption spectrum of the complexes is observed at $\lambda=475-492 \mathrm{~nm}$. Molar absorption coefficients are (3.1-3.3) $\times 10^{4}$. The stoichiometric ratio of the reacting components is Cr:HITP:Am = 1:3:3. The Beer's law is in effect in the range of $0.5-20 \mu \mathrm{g} / \mathrm{ml}$ chromium concentrations. Based on the evidence found, photometric methods for the determination of chromium in soils were developed.

Keywords: chromium, 2-hydroxy-5-iodthiophenol, xylidin, mixed-ligand complexes,
\end{abstract} extraction-photometric method

DOI: $10.32737 / 2221-8688-2019-4-518-525$

\section{Introduction}

Chromium is one of the toxic metals. Chromium (VI) compounds which are among the most dangerous pollutants of natural objects, have the most carcinogenic effect [12]. In this regard, in modern practical chemical analysis there is a need for the definition of this element-pollutant. Special control require drinking, natural and industrial water, the chromium content in which is strictly regulated. To assess the content of toxic components in various environmental objects, the methods based on the determination of elements with organic reagents are quite promising and actively developing [3].

Table 1. Characteristics of previously spectrophotometric methods for chromium determination

\begin{tabular}{|l|c|c|c|c|c|}
\hline Reagent* & $\begin{array}{l}\text { Linear range/ } \\
\mathrm{mg} \mathrm{L}^{-1}\end{array}$ & $\begin{array}{l}\lambda_{\max }, \\
\mathrm{nm}\end{array}$ & $\begin{array}{l}\text { Molar } \\
\text { absorptivity/ L } \\
\mathrm{mol}^{-1} \mathrm{~cm}^{-1} \\
\varepsilon \times 10^{-4}\end{array}$ & $\begin{array}{l}\text { Relative } \\
\text { standard } \\
\text { deviation/\% }\end{array}$ & Ref. \\
\hline Cr-EDTA & $6.0-160$ & 485 & 0.21 & 0.6 & {$[4]$} \\
\hline Cr-5-Br-DMPAP & $0.02-0.56$ & 546 & 7.8 & 2 & {$[4]$} \\
\hline Cr-PAR & - & 540 & 4.7 & - & {$[4]$} \\
\hline Cr-PAN & $0.3-2.0$ & 420 & 1.28 & 1.25 & {$[4$} \\
\hline Cr-TAR & $3.4-79$ & 390 & 4.51 & 0.95 & {$[5]$} \\
\hline Cr- HBTP- Ap1 & $4.1-5.3$ & 470 & 2.92 & 0.89 & {$[6]$} \\
\hline Cr- HBTP- Ap2 & $4.0-5.2$ & 465 & 3.28 & 0.95 & {$[6]$} \\
\hline
\end{tabular}

*Note: EDTA - ethylenediamine tetraacetic acid; TAR - 4-(2- Thiazolylazo)-resorcinol; PAR - 4-(2pyridylazo)resorcinol; PAN - 1-(2-Pyridylazo)-2-naphthol; 5-Br-DMPAP - 2-(5-bromo-2-pyridylazo)-5dimethylaminophenol); HBTP - 2-hydroxy-5-bromothiophenol; Ap1 - N, N-dimethylaminomethyl -4methylphenol; Ap2-N, N-dimethylaminomethyl -4-chlorophenol. 
The paper deals with research into conditions of interaction of chromium (VI) with 2-hydroxy-5-iodothiophenol (HITP, $\mathrm{H}_{2} \mathrm{~L}$ ). In the presence of hydrophobic amines, extraction of these compounds in the organic phase in the form of a mixed-ligand complex (MLC) is observed. Out of hydrophobic amines (HAs): -o-xylidine (o-xyl) and mxylidine (m-xyl) are used.

\section{Materials and methods}

Reagents. A solution of Chromium (VI) $\quad\left(1 \mu \mathrm{g} \mathrm{mL}^{-1}\right.$ was prepared through dissolving (0.1935) gm of $\mathrm{K}_{2} \mathrm{Cr}_{2} \mathrm{O}_{7}$ p. f. a. (pure for analysis) in $1000 \mathrm{ml}$ of water. Concentration of Chromium solution was established gravimetrically [7]. Working solution with concentration of $0,1 \mathrm{mg} / \mathrm{ml}$ was prepared by dilution of stock with deionized water. HITP was synthesized according to the method [8]. The purity was checked by paper chromatography and melting temperature determination. Chloroform was distilled before use. Chloroform solutions of HITF (0.01 $\mathrm{mol} / \mathrm{l})$ and Am (0.02 mol/l $)$ were used. To create optimal acidity, $0.1 \mathrm{~mol} / \mathrm{l}$ solutions of $\mathrm{HCl}, \mathrm{NaOH}$, or ammonium acetate $\left\{\mathrm{CH}_{3} \mathrm{COOH} \mathrm{CH}_{3} \mathrm{COONH}_{4}(\mathrm{pH} 4-12)\right\}$ were used.

Apparatus. The absorption of the extracts was read using a photocolorimeter KFK-2 and a spectrophotometer SP-26. For $\mathrm{pH}$ determination, an I-120.2 ionometer was used with a glass electrode.

Procedure. Portions of stock solutions of chromium (III) varying from 0.1 to $1.0 \mathrm{~mL}$ with a $0.1-\mathrm{mL}$ step, a $2.2 \mathrm{~mL}$ portion of a 0.01 $\mathrm{M}$ solution of HBTP, and a $2.5 \mathrm{~mL}$ portion of a $0.01 \mathrm{M}$ solution of Am were placed into calibrated test tubes with ground-glass stoppers (volume of the organic-phase was 5 $\mathrm{mL}$ ). A required value of $\mathrm{pH}$ was adjusted by adding $1 \mathrm{M} \mathrm{HCl}$. The volume of the aqueous phase was increased up to $20 \mathrm{~mL}$ using distilled water. In 15 minutes after complete separation of the phases, the organic phase was separated from the aqueous phase and the absorbance of the extracts was measured on KFK-2 at room temperature and $490 \mathrm{~nm}$
$(1=0.5 \mathrm{~cm})$.

\section{Determination of Chromium (III) in} soils. The proposed procedures for the determination of Chromium were applied in light-chestnut soil from the Caspian zone. A $0.5-\mathrm{g}$ weight was finely ground in an agate mortar and calcined in a muffle furnace for 3 h. after cooling, the sample was treated and dissolved in an graphite cup with a mixture of $16 \mathrm{~mL}$ of conc. $\mathrm{HF}, 5 \mathrm{~mL}$ of conc. $\mathrm{HNO}_{3}$, and $15 \mathrm{~mL}$ of conc. $\mathrm{HCl}$ at $50-60^{\circ} \mathrm{C}$ to remove excess hydrogen fluoride, a $8 \mathrm{~mL}$ portion of conc. $\mathrm{HNO}_{3}$ was added triply to the solution being every time evaporated to $5-6 \mathrm{~mL}$. After that, the solution was transferred to a $100 \mathrm{~mL}$ volumetric flask and its volume brought to the mark with distilled water. Chromium was determined in aliquot portions of the solution using the proposed procedures.

Chromium oxidation studies. It is known that hydroxyhalogenthiophenol has reducing properties in an acidic environment $[6,8]$. Previous studies with $\mathrm{Cr}(\mathrm{VI})-\mathrm{H}_{2} \mathrm{~L}-\mathrm{HAm}$ and $\mathrm{Cr}(\mathrm{III})-\mathrm{H}_{2} \mathrm{~L}-\mathrm{HAm}$ showed that only Cr(III) forms stable complexes with this reagent. To determine the degree of oxidation of chromium in the presence of HITP, we conducted two series of experiments. In the first series, we used $\mathrm{Cr}(\mathrm{VI})$, and in the second series -- $\mathrm{Cr}(\mathrm{III})$ obtained by adding an additional reducing agent $\left(\mathrm{SnCI}_{2}\right.$ or $\left.\mathrm{KI}\right)$. A comparison of the spectra obtained showed that $\lambda_{\max }\left[\mathrm{Cr}(\mathrm{VI})-\mathrm{H}_{2} \mathrm{~L}-\mathrm{HAm}\right]=\lambda_{\max }[\mathrm{Cr}(\mathrm{III})-$ $\left.\mathrm{H}_{2} \mathrm{~L}-\mathrm{HAm}\right]$. This fact can be considered as an indication $[6,8]$ that $\mathrm{Cr}(\mathrm{VI})$ is reduced to $\mathrm{Cr}(\mathrm{III})$ by the reagent itself during complex formation.

\section{Results and discussion}

Choice of solvent. For the extraction of complexes we used $\mathrm{CHCl}_{3}, \mathrm{CCl}_{4}, \mathrm{C}_{6} \mathrm{H}_{6}$, $\mathrm{C}_{6} \mathrm{H}_{5} \mathrm{CH}_{3}, \mathrm{C}_{6} \mathrm{H}_{4}\left(\mathrm{CH}_{3}\right)_{2}, \mathrm{C}_{2} \mathrm{H}_{4} \mathrm{Cl}_{2}$, iso-butanol

and iso-pentanol. Extractability of complexes was estimated at coefficient of distribution (D) and extent of extraction (R\%) [9]: 


$$
D=\frac{[W]_{\text {org }}}{[W]_{a q}} ; \quad R=\frac{100 \times D}{D+\frac{V_{a q}}{V_{\text {org }}}}
$$

The extractivity of the complexes was estimated by means of distribution and recovery coefficients. Chloroform, dichloroethane and chlorobenzene appeared to be the best extractants. Further investigations were carried out with chloroform. After a single extraction with chloroform, 97.4-98.8\% of chromium was extracted as an ion associate. The chromium content in the organic phase was determined photometrically from diphenylcarbazide [1] after desorption in the aqueous phase by difference.

Influence of the $\mathrm{pH}$ of the aqueous phase. Study into dependence of a complex formation from $\mathrm{pH}$ showed that the exit of complexes of chromium is maximum at $\mathrm{pH} 2.8$ - 4.7. Extraction of $\mathrm{Cr}$ (III) rose as the acidity of the initial solution increased; further rise in acidity led to gradual decrease of recovery which was obviously associated with decrease in the concentration of the ionized form of HITP. Probably, it is present in the solution in the non-dissociated state. At $\mathrm{pH} \geq 7$, the complexes were hardly extracted probably due to decrease in the degree of Am protonation. The effect of $\mathrm{pH}$ on the intensity of the color reaction is shown in Fig. 1 and Table 2. Existence of one maximum of absorbance in the specified limits $\mathrm{pH}$ reaffirms the formation of one complex connection.

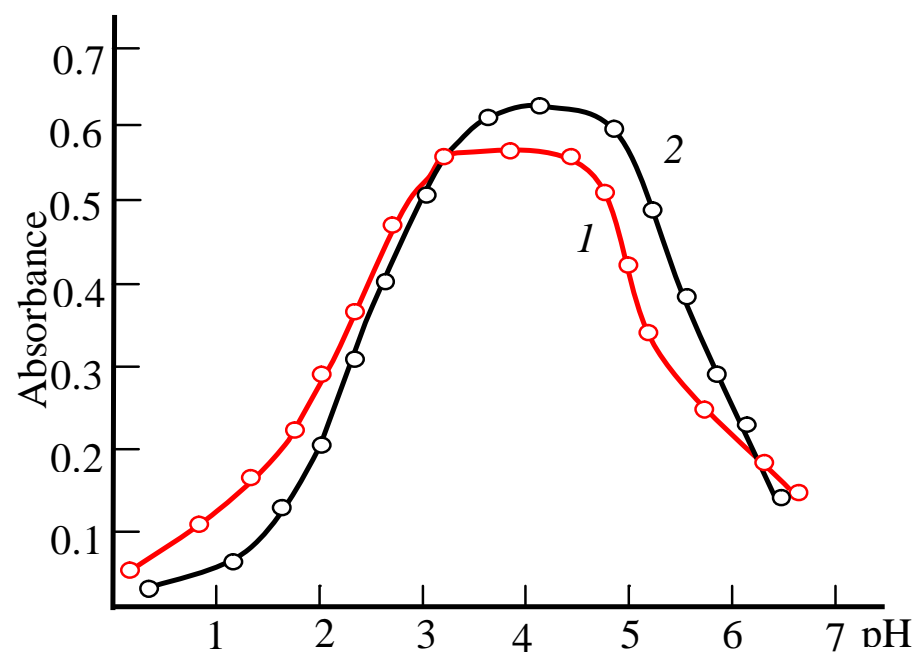

Fig. 1. Absorbance of mixed-ligand complexes as a function of the $\mathrm{pH}$ of the aqueous phase: 1Cr(III)-HITP-o-xyl; 2- Cr(III)-HITP- $m$-xyl. $\mathrm{C}_{\mathrm{Cr}}=3.84 \times 10^{-5} \mathrm{M} . \mathrm{C}_{\mathrm{HITP}}=1.0 \times 10^{-3} \mathrm{M}, \mathrm{C}_{\mathrm{Am}}=(1.12-$ 1.16) $\times 10^{-3} \mathrm{M}, \mathrm{KFK}-2, \lambda=490 \mathrm{~nm}, \ell=0.5 \mathrm{~cm}$.

Effect of reagent concentration. For the formation and extraction of MLC, a 26-30fold excess of complexing reagents is required; for example, the optimal conditions for formation and extraction of these compounds are provided by $1.0 \times 10^{-3} \mathrm{M}$ HITP and (1.121.16) $\times 10^{-3} \mathrm{M}$ Am. Note that a larger excess of hydrophob amin interferes with the determination. However, it was found that excess in the reagent solution does not alter absorbance of the color reaction.
The adherence to Beer's law was studied by measuring the absorbance value of the series of solutions containing different concentrations of the metal ion. A linear calibration graph drawn between absorbance and metal ion concentration indicates that $\mathrm{Cr}$ (III) may be determined in the range 0.5$20.0 \mu \mathrm{g} / \mathrm{ml}$.

Resistance to dyeing and extraction time. Unlike single-ligand complexes, mixedligand complexes of $\mathrm{Cr}$ (III) with HITP and Am were stable in aqueous and organic 
solvents and did not decompose for two days duration of the phase contact was 15 min. or over a month after extraction. The required

Table 2. Optimum conditions of education and analytical characteristic of chromium MLC with HITP and Am.

\begin{tabular}{|c|c|c|c|c|}
\hline Compound & $\begin{array}{c}\text { Optimum } \mathrm{pH} \\
\text { interval }\end{array}$ & $\lambda_{\max } / \mathrm{nm}$ & $\varepsilon \times 10^{-4} / \mathrm{L} \mathrm{mol}^{-1} \cdot \mathrm{cm}^{-1}$ & Working range $/ \mu \mathrm{g} / \mathrm{ml}$ \\
\hline Cr-HITP- o-Xyl & $3.1-4.5$ & 475 & 3.3 & $0.5-20$ \\
\hline Cr-HITP- m-Xyl & $3.5-4.7$ & 492 & 3.1 & $0.5-20$ \\
\hline
\end{tabular}

\section{Electronic absorption spectra.}

Neither metal ion nor reagent has appreciable absorbance at specified wavelengths. Hence, further studies were carried out at $475-492 \mathrm{~nm}$. The reagent has minimum absorbance in terms of complex maximum absorbance. Thus, further absorbance measurements were made at 490 nm. The molar absorptivity of the complex was calculated by means of Komar method [10] to be $\varepsilon=(3.1-3.3) \times 10^{4} \mathrm{~L} \mathrm{~mol}^{-1} \mathrm{~cm}^{-1}$.

\section{Stoichiometry of the complexes and} the mechanism of complexation. It was found, using the Nazarenko method, that $\mathrm{Cr}(\mathrm{III})$ in the complexes was present in the three charging cations $\mathrm{Cr}^{3+}$. The number of protons substituted by chromium in one HITP molecule turned out to be one [12].

The stoichiometric coefficients of the reaction were determined by the Asmus method, the relative yield method and the equilibrium shift method [10] (Fig. 2).
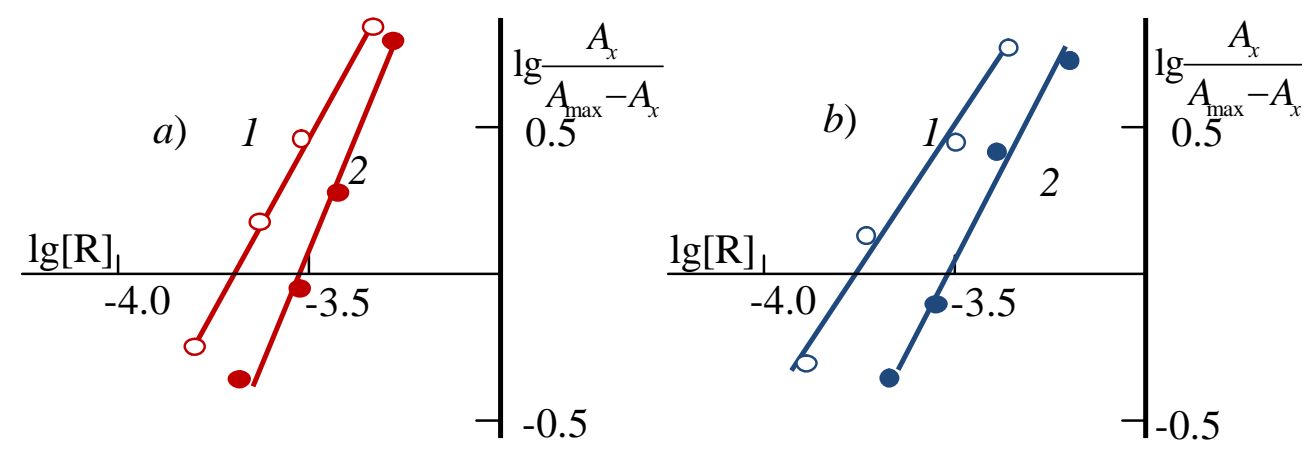

Fig. 2. Determination of the ratio of components by the equilibrium shift method for (a) Cr(III)-HITP-o-xyl and (b) Cr(III)-HITP-m-xyl. 1. Cr:HITP; 2.Cr : Am.

The formation of MLC can be offered as follows. When chromium ion interacts with three molecules of o-hydroxythiophenols, they form three-charged anionic complexes which are extracted with three molecules of protonated Am. The structure of the extracted complexes is shown below:

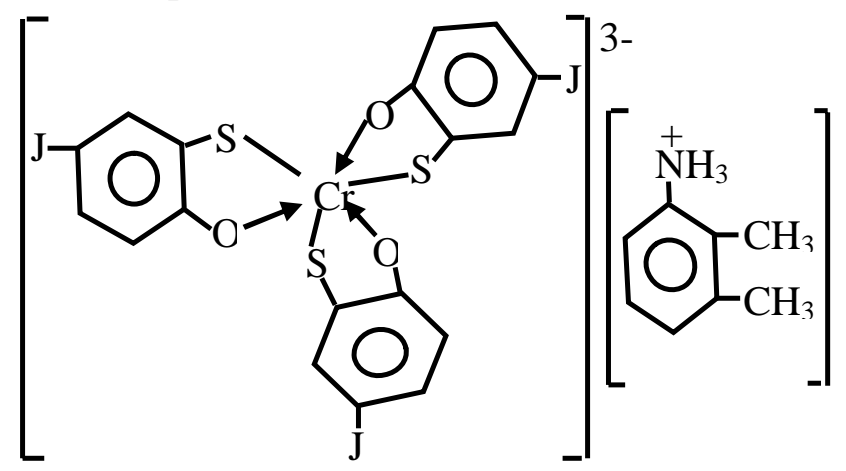


Several equilibrium processes should be taken into account for the system of $\left[\mathrm{Cr}(\mathrm{HL})_{3}\right]^{2-}-O$ $\mathrm{XylH}^{+}-\mathrm{H}_{2} \mathrm{O}-\mathrm{CH}_{3} \mathrm{Cl}$. Formation of ion- association complex in the aqueous phase is as follows:

$$
\left[\mathrm{Cr}(\mathrm{HL})_{3}\right]^{2-}+3 \mathrm{AmH}^{+} \leftrightarrow\left(\mathrm{AmH}^{+}\right)_{3}\left[\mathrm{Cr}(\mathrm{HL})_{3}\right]
$$

Distribution of the complex between the aqueous and the organic phases:

$$
\left(\mathrm{AmH}^{+}\right)_{3}\left[\mathrm{Cr}(\mathrm{HL})_{3}\right]_{(\mathrm{aq})} \leftrightarrow \quad\left(\mathrm{AmH}^{+}\right)_{3}\left[\mathrm{Cr}(\mathrm{HL})_{3}\right]_{(\mathrm{org})}
$$

Extraction from water into chloroform:

$$
\left[\mathrm{Cr}(\mathrm{HL})_{3}\right]_{(\mathrm{aq})}+3\left(\mathrm{AmH}^{+}\right) \leftrightarrow\left(\mathrm{AmH}^{+}\right)_{3}\left[\mathrm{Cr}(\mathrm{HL})_{3}\right]_{(\mathrm{org})}
$$

Based on the equation as follows:

$$
\begin{gathered}
\beta=\frac{\left\{\left[\mathrm{Cr}(\mathrm{HL})_{3}\right](\mathrm{AmH})_{3}\right\}}{\left[\mathrm{Cr}(\mathrm{HL})_{3}^{3-}\right]\left[\mathrm{AmH} \mathrm{H}^{+}\right]^{3}} \\
K=\frac{\left\{\left[\mathrm{Cr}(\mathrm{HL})_{3}\right](\mathrm{AmH})_{3}\right\}_{\text {org }}}{\left\{\left[\mathrm{Cr}(\mathrm{HL})_{3}\right](\mathrm{AmH})_{3}\right\}_{a q}} \\
K_{e x}=K_{D}+\beta=\frac{\left\{\left[\mathrm{Cr}(\mathrm{HL})_{3}\right](\mathrm{AmH})_{3}\right\}_{a r g}}{\left\{\left[\mathrm{Cr}(\mathrm{HL})_{3}^{3-}\right]\right\}_{a q}\left\{\left(\mathrm{AmH} \mathrm{H}^{+}\right)_{3}\right\}_{a q}}
\end{gathered}
$$

Note that constants of the association $\beta$ were determined by means of independent methods: Mobile equilibrium method [12], HolmeLangmyhr method [13], Komar-Tolomachev Method [10] and Harvey-Manning method [14].

Constants of the distribution $\mathrm{K}_{\mathrm{D}}$ were determined by comparison of the absorbance values obtained due to a single extraction under optimum conditions $\left(\mathrm{A}_{1}\right)$ and triple extraction $\left(A_{3}\right): K_{D}=A_{1} /\left(A_{3}-A_{1}\right)$. Extraction constants were calculated by the equation Kex $=\beta+\mathrm{K}_{\mathrm{D}}$ [10]. All calculations were carried out at a probability of $95 \%$. Obtained values are shown in Table 3.

Table 3. Values of the extraction constants $\left(\mathrm{K}_{\mathrm{ex}}\right)$, distribution constants $\left(\mathrm{K}_{\mathrm{D}}\right)$, association constants $(\beta)$ and recoveries (R\%) for the Cr(III)- HTPD -Am-water-chloroform systems

\begin{tabular}{|l|l|l|l|l|}
\hline Extraction system & $\lg \beta$ & $\operatorname{lgK} \mathrm{D}_{\mathrm{D}}$ & $\operatorname{lg~} \mathrm{e}_{\mathrm{ex}}$ & $\mathrm{R} \%$ \\
\hline $\mathrm{Cr}(\mathrm{III})-\mathrm{H}_{2} \mathrm{~L}-\mathrm{o}-\mathrm{xyl}-\mathrm{H}_{2} \mathrm{O}-\mathrm{CHCl}_{3}$ & $9.57 \pm 0.2^{\mathrm{a}}$ & $1.86 \pm 0.01$ & $11.43 \pm 0.33^{\mathrm{e}}$ & 98.7 \\
& $9.82 \pm 0.4^{\mathrm{b}}$ & & $11.69 \pm 0.23^{\mathrm{f}}$ & \\
& $9.34 \pm 0.7^{\mathrm{c}}$ & & & \\
& $9.39 \pm 0.3^{\mathrm{d}}$ & & & \\
\hline $\mathrm{Cr}(\mathrm{III})-\mathrm{H}_{2} \mathrm{~L}-\mathrm{m}-\mathrm{xyl}-\mathrm{H}_{2} \mathrm{O}-\mathrm{CHCl}_{3}$ & $9.28 \pm 0.3^{\mathrm{b}}$ & $1.42 \pm 0.08$ & $10.56 \pm 0.38^{\mathrm{e}}$ & 97.4 \\
\hline
\end{tabular}

Note: ${ }^{a}$ Calculated by the Holme-Langmyhr method [13]; ${ }^{b}$ Calculated by the Harvey-Manning method [14]; ${ }^{c}$ Calculated by the Komar-Tolmachev method [10]; ${ }^{d}$ Calculated by the mobile equilibrium method [12]; ${ }^{e}$ Calculated by the formula $K_{e x}=K_{D}+\beta$ where $b$ is determined by the Holme-Langmyhr method [29]; ${ }^{f}$ Calculated by the formula $K_{e x}=K_{D}+\beta$ where $b$ is determined by the Harvey-Manning method [14].

Calculation of extent of polymerization of complexes was carried out on the equation. The made calculations showed that MLC in an organic phase won't be polymerized and are in a monomeric form $(\gamma=1.02-1.18)$.

Influence of interfering ions. To evaluate the complex applicability for photometric determination of chromium, we examined the influence of foreign ions and reagents. The results showed that great excesses of alkali, alkali earth, and rare earth elements, as well as $\mathrm{NO}_{3}^{-}, \mathrm{ClO}_{4}^{-}, \mathrm{SO}_{4}{ }^{2-}$ and $\mathrm{CH}_{3} \mathrm{COO}^{-}$do not interfere determination of chromium with HTPD and Am. Interference of most cations is masked by the addition of complexone III. Tartrate mask the milligram quantities of $\mathrm{Ta}, \mathrm{Ti}, \mathrm{W}$ and Mo. Zr fluorides should mask, and copper-thiourea. 
Analytical characteristics. Equations of obtained straight lines and some important complexes for extractive-spectrophotometric characteristics over application of ternary determination of $\mathrm{Cr}(\mathrm{III})$ are listed in Table 4.

Table 4. Analytical characteristics

\begin{tabular}{|l|c|c|}
\hline \multirow{2}{*}{ Characteristic } & \multicolumn{2}{|c|}{ Extraction system } \\
\cline { 2 - 3 } & Co-HIPT- o-xyl & Co-HIPT- m-xyl \\
\hline Apparent molar absorptivity $(\varepsilon), \mathrm{L} \mathrm{mol}^{-1} \mathrm{~cm}^{-1}$ & $3.3 \times 10^{4}$ & $3.1 \times 10^{4}$ \\
\hline Adherence to Beer's law, $\mu \mathrm{g} \mathrm{mL}{ }^{-1}$ & $0.5-20$ & $0.5-20$ \\
\hline Equation of the straight line & $0.1237 x+0.062$ & $0.1254 x+0.038$ \\
\hline Coefficient of correlation & 0.9995 & 0.9992 \\
\hline Sandell's sensitivity, $\mathrm{ng} \mathrm{cm}^{-2}$ & 0.00852 & 0.00748 \\
\hline Limit of detection, $\mu \mathrm{g} \mathrm{mL}^{-1}$ & 13 & 15 \\
\hline Limit of quantification, $\mu \mathrm{g} \mathrm{mL}^{-1}$ & 40 & 42 \\
\hline
\end{tabular}

Table 5 demonstrates the data which allow a procedures for the determination of chromium comparison of the analytical parameters of the with the earlier known procedures [4].

Table 5. Comparative characteristics of procedures for determining chromium

\begin{tabular}{|l|c|c|c|c|c|}
\hline \multicolumn{1}{|c|}{ Reagent } & $\mathrm{pH}$ ( solvent) & $\lambda, \mathrm{nM}$ & $\varepsilon \cdot 10^{-4}$ & Beer's law range, $\mu \mathrm{g}$ & [Ref.] \\
\hline 5-Br-DMPAP & $0.1-10 \mathrm{M} \mathrm{HCl}\left(\mathrm{CHCl}_{3}\right)$ & 546 & 7.8 & $0.02-0.56$ & 4 \\
\hline PAR & $4-5$ & 540 & 4.7 & $3.2-13.0$ & 4 \\
\hline PAN & $0.2-0.8 \mathrm{M} \mathrm{HCl}$ (aseton) & 420 & 1.28 & $0.3-2.0$ & 4 \\
\hline \multicolumn{5}{|c|}{ Proposed method } \\
\hline \multicolumn{7}{|c|}{ Cr-HITP- o-Xyl } & $3.1-4.5\left(\mathrm{CHCl}_{3}\right)$ & 475 & 3.3 & $0.5-20$ & \\
\hline Cr-HITP- -Xyl & $3.5-4.7\left(\mathrm{CHCl}_{3}\right)$ & 492 & 3.1 & $0.5-20$ & \\
\hline
\end{tabular}

Analytical applications. The proposed method in the already established optimal conditions was applied to determine Cr (III) in soils. Also, procedures for determining chromium in soils were verified by diphenylcarbazide methods. The results of the analysis are listed in Table 6 to indicate successful applicability of the proposed method for real sample analysis.

Table 6. Correctness and reproducibility of determination of chromium in soil $(n=5, P=0.95)$

\begin{tabular}{|l|c|c|c|c|}
\hline \multirow{2}{*}{ Method } & $\mathrm{X}^{-}, \% \times 10^{-4}$ & $\mathrm{SD} \times 10^{-4}$ & $\mathrm{RSD}, \%$ & $\overline{\mathrm{X}} \pm \frac{t_{P} \cdot S}{\sqrt{n}}$ \\
\hline \multicolumn{5}{|c|}{ Standard method } \\
\hline Diphenylcarbazide & 2.89 & 0.156 & 6 & $(2.89 \pm 0.027)$ \\
\hline \multicolumn{5}{|c|}{ Proposed method } \\
\hline HITP-o-xyl & 2.80 & 0.123 & 7 & $(2.80 \pm 0.013)$ \\
\hline HITP- $m$-xyl & 2.84 & 0.141 & 5 & $(2.84 \pm 0.032)$ \\
\hline
\end{tabular}

\section{References}

1. Lavrukhina A.K., Iukina L.V. 2. Saranchina N.V., Mikheev I.V., Gavrilenko Analiticheskaia khimiia khroma [Analytical chemistry of chromium]. Moscow: Nauka Publ.,1979, 219 p. (In Russian).

N.A. Determination of chromium(VI) using 1,5-diphenylcarbazide immobilized in a polymethacrylate matrix. Analitika i kontrol 
[Analytics and control]. 2014, vol. 18. no. no. 1, pp.105-111. (In Russian).

3. Fomin G.S. Voda. Kontrol khimicheskoi, bakterialnoi $i$ radiatsionnoi bezopasnosti po mezhdunarodnym standartam [Control of chemical, bacterial and radiation safety according to international standards]. Moscow: Protektor Publ., 2010. 1008 p. (In Russian).

4. Pyatnitskiy I.V. Analiticheskaya khimiya kobalta [Cobalt Analytical Chemistry]. Moscow: 1965, 215 p. (In Russian).

5. Luciene S.C., Antonio C.S., Sérgio L.C., Leonardo S.G. Spectrophotometric determination of chromium in steel with 4(2- thiazolylazo)-resorcinol using microwave radiation. J. Braz. Chem. Soc. 2004, vol.15. no. 1, pp. 153-157.

6. Mamedova R.K, Aliyev S.G., Hasanova N.S., Verdizadeh N.A., Zalov A.Z. Extraction-spectrophotometric study of ternary complexes of $\mathrm{Cr}$ (VI) using $o$ hydroxythiophenols and Aminophenol. International Journal of Chemical Studies. 2017, vol. 5. no. 4, pp.1255-1262.

7. Korostelev P.P. [Preparation of solutions for chemical analysis works]. Moscow: Publishing house of Academy of Sciences of the USSR. 1964, p. 401.

8. Novruzova N.A., Verdizade N.A., Mamedova R.A., Zalov A.Z. A study of complex formation of tungsten(VI) with 2hydroxy-5-bromothiophenol and aminophenols. Chemical problems. 2018, vol. 16. no. 1, pp. 105-113.
9. Zalov A.Z., Verdizade N.A. Extraction spectrophotometry determination of tungsten with 2-hydroxy-5chlorothiophenol and hydrophobic amines. Zhurnal Analiticheskoj Khimii - Journal of Analytical Chemistry. 2013, vol. 68, pp. 212-217. (In Russian).

10. Bulatov M.I., Kalinkin I.P. Prakticheskoe rukovodstvo po fotokolorimetricheskim I spektrofotometricheskim metodam analiza [Practical Guide on Photocolorimetric and Spectrophotometric Methods of Analysis]. Moscow: Khimiya Publ. 1986, p. 432.

11. Nazarenko V.A., Biryuk E.A. A study of the chemistry of reactions of multi-valent element ions with organic reagents. Zhurnal Analiticheskoj Khimii - Journal of Analytical Chemistry. 1967, vol. 22, no. 1, pp. 57-64. (In Russian).

12. Zhiming Z, Dongsten M and Cunxiao Y. Mobile equilibrium method for determining composition and stability constant of coordination compounds of the form $\mathrm{M}_{m} R_{n}$. Journal Rare Earth. 1997, vol.15. no.2, pp. 216-220.

13. Holme A., Langmyhr F.J. A modified and a new straight-line method for determining the composition of weak complexes of the form $\mathrm{A}_{\mathrm{m}} \mathrm{B}_{\mathrm{n}}$. Anal. Chim. Acta. 1966, vol. 36. no. 3, pp. 383-387.

14. Harvey A.E., Manning D.L. Spectrophotometric Methods of establishing empirical formulas of colored complexes in solution. Journal Amer. Chem. Soc. 1950, vol.72. no 8, pp. 44884453.

\title{
XROMUN 2-HIDROKSI-5-YODTIOFENOL VO HIDROFOB AMIN ISTTIRAKINDA KOMLEKS OMӘLӘGOLMӘ REAKSIYASININ TODQIQI
}

\author{
N.S. Hasənova \\ Azarbaycan Dövlat Neft va Sanaye Universiteti \\ AZ 1000 Bakl, Azadlıq küçəsi, 34; e-mail: hesenova.1969@inbox.ru
}

Xromun 2-hidroksi-5-yodtiofenol (HYTF) va hidrofob aminlarla (Am) kompleks amalagalma reaksiyalarl spektrofotometrik tadqiq edilmişdir. Hidrofob aminlardan o-ksilidin va m-ksilidin istifado edilmişdir. Әn yaxşl ekstragent kimi xloroform, dixloretan va xlorbenzol müəyyən edilmişdir. Xloroformla birdafalik ekstraksiyada xromun 97.4-98.8\%-i ion assosiat şəklindo ekstraksiya olunur. Müayyan edilmişdir ki, ion assosiatlar zaif turş mühitdo amala galir ( $p H$ 0.2- 
6.9). İon assosiatların amalagalmasi va ekstraksiyası üçün kompleksəmalagatirici reagentlarin 26-30 dafa artı̆̆ talab olunur. Bu birlaşmalarin amalagalmasi va ekstraksiyası üçün $1.0 \times 10^{-3} \mathrm{M}$ HITP u (1.12-1.16) $\times 10^{-3} \mathrm{M}$ Am talab olunur. Udma spektrindo maksimum $\lambda=475-492 \mathrm{HM}$ - do müşahida olunur. Molyar işıqudma amsalı (3.1-3.3) $\times 10^{4}$ toşkil edir. Qarşılıqlı tasirda olan komponentlarin stexiometrik nisbəti Cr: HITP: Am = 1:3:3 kimidir. Ber qanununa tabe olma xromun $0.5-20 \mathrm{mkq} / \mathrm{ml}$ qatılı̆̆ında müşahidə olunur. Alınan nəticəlar asasında torpaqda xromun tayini üçün fotometrik metodlar işlənib hazırlanmışdır.

Açar sözlor: xrom, 2-hidroksi-5-yoditiofenol, ksilidin, qarlşlq-ligand komplekslor, ekstraksiyafotometrik metod

\section{ИЗУЧЕНИЕ РЕАКЦИИ КОМПЛЕКСООБРАЗОВАНИЯ ХРОМА (VI) C 2-ГИДРОКСИ-5-ИОДТИОФЕНОЛОМ В ПРИСУТСТВИИ ГИДРОФОБНЫХ АМИНОВ}

\section{Н.С. Гасанова}

Азербайджанский государственный университет нефти и промышленности AZ1000 Баку, ул.Азадльл,,34, e-mail: hesenova.1969@inbox.ru

Спектрофотометрическими методами изучена реакиия комплексообразования хрома (VI) c 2-гидрокси-5-йодтиофенолом (НІТР) в присутствии гидрофобных аминов. Из гидрофобньхх аминов использовань (Am): $\alpha$-оксилидин и м-ксилидин. Хлороформ, дихлорэтан и хлорбензол были лучшими экстрагентами. После однократной экстракции хлороформом 97.4-98.8\% хрома экстрагировали в виде ионного ассоциата (ИА). Установлено, что ИА образуются в слабокислой среде (рН 0.2-6.9). Для образования и экстракции ИА требуется 26-30-кратный избыток комплексообразующих агентов; например, оптимальные условия для образования и извлечения этих соединений обеспечиваются $1.0 \times 10^{-3}$ M НІТР и (1.12-1.16) $\times 10^{-3}$ M Ат. Максимум в спектре поглощения комплексов наблюдается при $\lambda=475-492$ нм. Молярные коэффициенты поглощчения составляют $(3.1-3.3) \times 10^{4}$. Стехиометрическое соотношение реагируюших компонентов составляет Cr: НITP: Am = 1:2:2. В диапазоне конщентраций хрома 0.5-20 мкг/мл наблюдается закон Бера. На основании полученных данных разработаны фотометрические методы определения хрома в почвах.

Ключевые слова: хром, 2-гидрокси-5-йодтиофенол, ксилидин, смешано-лигандные комплексы, экстракционно-фотометрический метод 